Подальшого дослідження потребує проблема формування готовності викладачів ВНЗ до виховання творчої особистості студента.

\title{
Література
}

1. Выготский Л. С. Собрание починений : в 6-ти томах / Л. С. Выготский. - М. : Педагогика, 1984. - Т. 4 : Детская психология. - 1984. - 432 с. 2. Боришевский М. И. Развитие саморегуляции поведения / М. И. Боришевский. - К. : Искусство, 1992. - 168 с. 3. Кан-Калик В. А. Педагогическое творчество / В. А. Кан-Калик, Н. Д. Никандров. - М. : Педагогика, 1990. - 144 с. 4. Кичук Н. В. Формування творчої особистості вчителя / Н. В. Кичук. - К. : Знання, 1991. - 96 с. 5. Лук А. Н. Психология творчества / А. Н. Лук. М. : Наука, 1978. - 127 с. 6. Моляко В. О. Психологічна готовність до творчої праці / В. О. Моляко. - К. : Знання, 1989. - 48 с. 7. Поташник М. М. Психологія розвитку творчої особистості: [навч. посібн.] / М. М. Поташник, В. В. Рибалка. - К. : ІЗМН, 1996. 236 с. 8. Рувинский Л. И. Теория самовоспитания / Л. И. Рувинский. - М. : Изд-во Московского ун-та, 1973. - 263 с. 9. Сисоєва С. О. Педагогічна творчість : [монографія] / С. О. Сисоєва. - К. : Каравела, $1998 . \quad-150$ с. 10. Сухомлинський В. О. Вибрані твори у 5-ти томах / В. О. Сухомлинський. - К. : Радянська школа, 1976. - Т.1. - 1976. $509 \mathrm{c}$.

Н. О. Побережна, кандидат пед. наук, доцент, Дніпропетровський регіональний інститут державного управління

\section{ДО ПРОБЛЕМИ МОДЕЛЮВАННЯ НАВЧАЛЬНОГО ПРОЦЕСУ НА ОСНОВІ ІНФОРМАЦІЙНИХ ТЕХНОЛОГІЙ}

У статті розглянуто деякі аспекти моделювання навчального прочесу на основі інформаційних технологій, представлено структуру навчальнометодичного комплексу на основі інформаційних технологій.

Ключові слова: прочес навчання, комп'ютерно-орієнтоване навчальне середовище, інформаційні технологї̈ навчання.

В статье рассматриваются некоторые аспекты моделирования учебного процесса на основе информационных технологий, представлена структура учебно-методического комплекса на основе информачионных технологий.

Ключевые слова: прочесс обучения, компьютерно-ориентированная учебная среда, информачионные технологии обучения. 
The article investigates the peculiarities of modeling educational process based on information technologies, the structure of curriculum and instructional kit is presented on the basis of information technologies.

Key words: educational process, computer-oriented educational environment, information technologies of education.

Сучасний етап розвитку українського освітнього простору характеризується його системним реформуванням, підтримкою інноваційного розвитку, переходом до багатогранності не тільки як до перспективної тенденції, а й зовсім нової якості. Метою реформування $є$ як підвищення фундаментальності освіти, так і посилення її практичної спрямованості, інтенсифікації освітнього процесу за рахунок раціонального поєднання традиційних й інноваційних форм навчання, реалізації дидактичних завдань відповідно до мети і змісту навчання, інформатизації освіти, яка грунтується на впровадженні інформаційних технологій навчання.

Інтернет став невід'ємною складовою частиною освіти. Це найбільш адекватний інструмент для реалізації концепції безперервної освіти. А. Андреєв здійснив аналіз існуючих підходів до використання мережі Інтернет в освітньому процесі і класифікував інтернет-навчання отже: «чисте інтернетнавчання» (Ч-IН) і «комплексне» інтернет-навчання (К-IH), що мають, у свою чергу, багато видів і підвидів, які на жаль важко проаналізувати і систематизувати через існування реального розмаїття моделей $[1$, с. 4$]$.

Інтернет-технології часто включаються до традиційно функціонального навчального процесу освітнього закладу. У такому випадку інтернет-навчання існуе як деякий додатковий або альтернативний варіант навчання поряд із традиційно властивою цьому навчальному закладу моделлю навчання: інтернет-технології застосовуються в окремих видах занять (наприклад, замість звичайного семінару викладач організовує дискусію на форумі), із навчального плану за спеціальністю студент може обрати окрему дисципліну, яка вивчається ним у віртуальному варіанті (у подальшому вона зараховується студентові як вивчена в очному варіанті) тощо.

Нині (і найближчої перспективі), на думку багатьох дослідників, найбільш розповсюдженими будуть моделі змішаного навчання, тобто включення інтернет-технологій до традиційного навчального процесу. Так, для характеристики сучасного навчального середовища існує значна кількість тер- 
мінів та їх різних означень. Серед них: відкрите навчальне середовище, інформаційно-навчальне середовище, середовище дистанційного навчання, інтерактивне середовище, віртуальне середовище та ін.. Спільним для всіх цих понять $є$ те, що, здебільшого, йдеться про навчальне середовище, яке характеризується використанням мережних та інформаційних технологій для підтримки процесу навчання. Узагальнити ці терміни певною мірою можна за допомогою поняття «комп'ютерно-орієнтоване навчальне середовище», що охоплює будь-які аспекти використання комп'ютера в навчанні. Отже, ком'ютерно-орієнтоване навчальне середовище - це структурно упорядкована інформаційною технологією множина елементів системи інформаційних засобів навчання, які застосовуються для ресурсного забезпечення навчальновиховного процесу [3, с. 184].

Із метою підвищення ефективності застосування інформаційних технологій у навчальному процесі комп'ютерноорієнтоване навчальне середовище повинне, на нашу думку, забезпечувати: 1) створення ситуації інтелектуальних труднощів; 2) провокування обов'язковості прийняття рішення та його підтвердження певною дією; 3) візуалізацію результатів прийнятого рішення; 4) умови для самостійної організації навчально-пізнавальної діяльності, можливість коректування та повторення дій; 5) необхідну достатність інформації для автономної роботи.

Спрямованість комп'ютерно-орієнтованого навчального середовища дозволяє сформулювати вихідні вимоги до нього.

По-перше, для забезпечення ефективного керування впровадженням інформаційних технологій у процес навчання комп'ютерно-орієнтоване навчальне середовище повинно забезпечити як зовнішнє керування ним, так і саморегуляцію студентами своєї діяльності. Самостійна навчальнопізнавальна діяльність, за умов комп'ютерно-орієнтованого середовища, інтегрує як компоненти діяльності викладачів (стимулювальну, змістовну та організаційну), так і компоненти діяльності студентів (мотиваційну, операційну, результативну) [4, с. 283].

По-друге, підвищення якості засвоєння навчального матеріалу можна забезпечити, якщо зорієнтувати комп'ютерноорієнтоване навчальне середовище на синтез вербальноаналітичного й інтуїтивно-образного компонентів мислення тих, кого навчають, за допомогою використання 
комп'ютерної геометрії, графіки і високого інтерактивного режиму роботи.

По-третє, орієнтація на конкретний тип пізнавальної діяльності (репродуктивну чи творчу) тих, кого навчають, за рахунок інтеграції проблемного та програмованого підходів і досягнення гарантованого успіху в результаті інтелектуальних зусиль. При цьому формується мотивація досягнення, яка визначається за рівнями інтелектуальної активності: стимульно-продуктивної, евристичної, креативної.

По-четверте, актуальність комп'ютерно-орієнтованого навчального середовища, яка висуває не тільки навчальну проблему, але $\epsilon$ одночасно й «експериментальним майданчиком» для здійснення самостійної навчально-пізнавальної діяльності тих, кого навчають, шляхом самостійного планування, самоаналізу результатів і корекції своїх дій.

Вагомим чинником $\epsilon$ і комфортність застосування програмно-педагогічних засобів, завдяки дружній формі інтерфейсу, що сприяє підвищенню мотивації до навчання і стимулює бажання подолати пізнавальні труднощі.

Необхідно також зазначити, що органічне впровадження комп'ютерно-орієнтованих технологій до загального процесу вивчення навчальної дисципліни забезпечує можливість ii дистанційного вивчення.

Під час моделювання навчального процесу на підставі інформаційних технологій, до комп'ютерно-орієнтованого навчального середовища нами віднесено такі програмні елементи:

1. Технології та програмне забезпечення, що застосовуються для формування професійної компетентності в галузі базових знань і навичок щодо застосування комп'ютерних програм і телекомунікацій (операційна система та їі функціональні можливості, засоби створення, редагування та конвертування текстової, графічної, аудіо-відео інформації та електронних таблиць, засоби комунікацій, загальні принципи роботи в мережі Internet та користування іiі сервісами).

2. Системи та методи ефективного пошуку інформації у локальних та глобальних базах знань. Використання Internetпошукових систем для ефективного пошуку інформації різних типів та форматів.

3. Інформаційні технології для різних спеціальностей (професійні програми). 
4. Прикладне програмне забезпечення (спеціалізовані програмні комплекси для наочності лекційного та практичного курсів, програми для моделювання процесів та явищ, спеціалізовані вузькопрофільні навчальні пакети).

5. Системи тестування студентів, що дозволяють визначити якість їх знань, ступень формування особистих ділових якостей як майбутніх спеціалістів, психологічний стан сприйняття інформації, явні недоліки при опануванні матеріалу.

Отже, засоби навчання, у тому числі й ті, що функціонують на основі інформаційних технологій, у сукупності 3 навчально-методичними матеріалами утворюють навчальнометодичний комплекс на основі інформаційних технологій.

До структури навчально-методичного комплексу на основі інформаційних технологій ми відносимо навчальну й методичну літературу, програмне забезпечення, а також апаратну й програмну частину засобів навчання. (Рис. 1).

Слід зауважити, що програмних засобів інформаційнокомп'ютерних технологій $є$ досить багато. Вони можуть відрізнятися за інтерфейсом, спектром утиліт, платформами, водночас їх об'єднує можливість підтримки процесу навчання. До основних функцій таких програм можна віднести: а. можливість підтримки пояснення нового матеріалу; б. організація контролю навчальних досягнень; в. організація позаурочної діяльності у формі дистанційних консультацій.

Як слушно зауважує О. Співаковський, застосування інформаційних технологій навчання дає можливість викладачеві урізноманітнювати поєднання методів, методик навчання, підсилювати вплив на студентів. Вибір методів навчання дисципліні обумовлено важливою метою процесу навчання спрямованістю не тільки на розвиток виконавської, відновлювальної діяльності студентів, але і їх творчих здібностей, формування знань, умінь та навичок, необхідних для самостійного пізнання нових питань теорії, завдань у новій постановці. Для того, щоб ефективно використовувати обрані методи, викладачеві важливо визначитись у тому, коли, в яких випадках і чому краще використовувати один метод, коли інший, як вони узгоджуються 3 конкретною метою навчання, а також $з$ іншими елементами методичної системи (змістом, засобами, організаційними формами навчання), у якому співвідношенні повинні виступати вони в процесі навчання [5, c. 324]. 
Отже, в умовах модернізації вищої професійної освіти в системі впровадження інформаційних технологій відображаються нові структурні елементи та необхідні умови їх інтеграції в освітній процес вищої школи. Тільки здійснення необхідних змін в елементах інформаційних технологій і їх середовища може забезпечити адаптованість уведеному елементу системи - інформаційним технологіям навчання; а вся педагогічна система набуде нової, більш високої якості, що забезпечить підготовку молодих спеціалістів в умовах ринкової економіки.

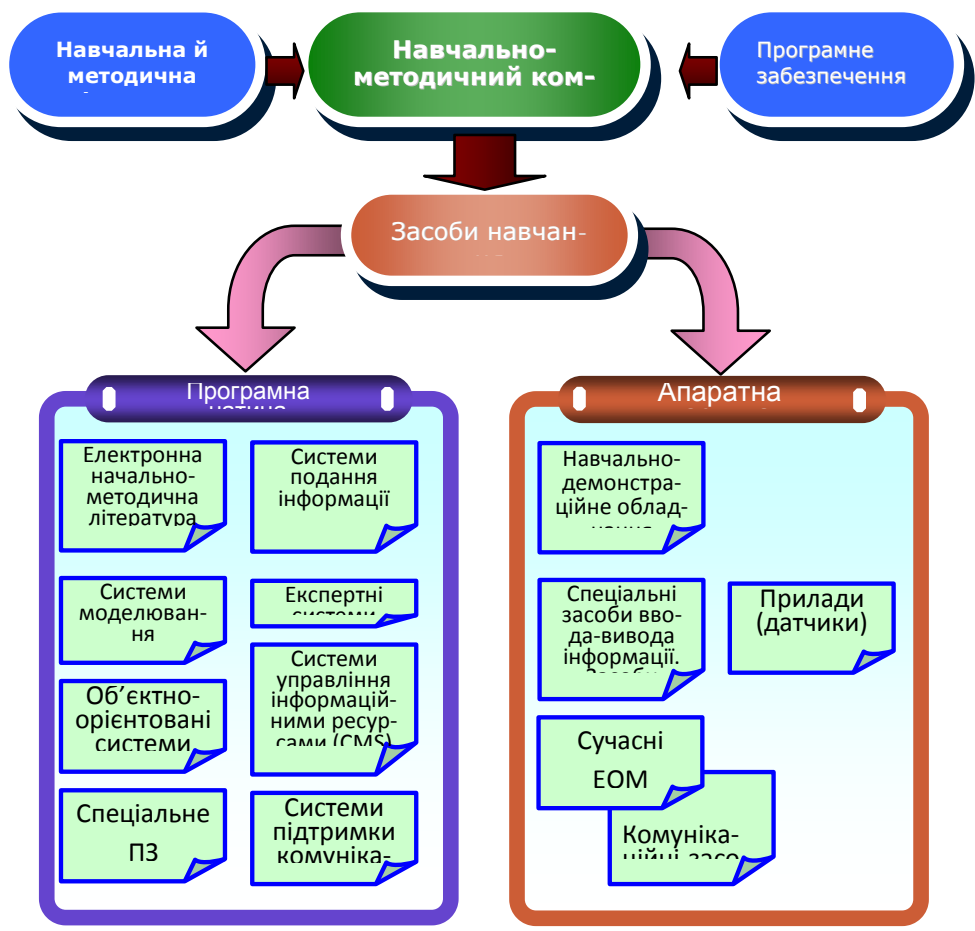

Рис. 1. Структура навчально-методичного комплексу на основі інформаційних технологій

\section{Література}

1. Андреев А. А. Применение сети Интернет в учебном процессе / А. А. Андреев // Информатика и образование. - 2005. - № 9. - С. 2 -7. 2. Биков В. Ю. Теоретико-методологічні засади моделювання навчального середовища сучасних педагогічних систем / В. Ю. Биков, Ю. О. Жук // Проблеми та перспективи формування національної гуманітарно-технічної еліти : [зб. наук. праць]. - 2003. - №1 (5). - 
С. 64 - 76. 3. Гуревич Р. С. Інформаційно-телекомунікаційні технології в навчальному процесі та наукових дослідженнях. / Р. С. Гуревич, М. Ю. Кадемія. - К. : Освіта України, 2006. - 390 с. 4. Кадемія М. Ю. Використання електронного навчальнометодичного комплексу в навчальному процесі / М. Ю. Кадемія // Сучасні інформаційні технології та іноноваційні методики навчання у підготовці фахівців: методологія, теорія, досвід, проблеми : [зб. наук. пр.]. - Випуск 8 / редкол.: І. А. Зязюн (голова) та ін. - Київ-Вінниця: ООО «Планер», 2005. - 547 с. 5. Співаковський О. В. Теоретико-методичні основи навчання вищої математики майбутніх вчителів математики з використанням інформаційних технологій : дис. ... д-ра пед. наук / О. В. Співаковський. - Київ, 2003. $535 \mathrm{c}$.

УДК 53(07):371,385

Г. П. Половина,

доиент,

Криворізький педагогічний інститут

ДВНЗ «Криворізький національний університет»

\section{ПАРТНЕРСЬКЕ НАВЧАННЯ УЧЕНЬ - СТУДЕНТ ПЕДАГОГІЧНОГО ВНЗ У САМОСТІЙНОМУ ВИВЧЕННІ ФІЗИКИ}

У роботі розглянуто один із підходів підвищення мотивачії навчання при дослідженні явища, яке викликало інтерес. До розв'язання иієї проблеми залучаються вчитель та викладач вищої школи, а також учень та студент педагогічного ВНЗ.

Ключові слова: партнерське навчання, самостійна діяльність, дослідницька робота, творче мислення.

В работе рассматривается один из подходов повышения мотивачии обучения при исследовании явления, которое вызвало интерес. К решению этой проблемы вовлекаются учитель и преподаватель высшей школь, а также ученик и студент педагогичного института.

Ключевые слова: партнерское обучение, самостоятельная деятельность, исследовательская работа, творческое мышление.

In this work one of motivation increase approaches of training at research of the phenomenon with caused interest is considered. To the solution of this problem the teachers and professors of higher educational institution and also the pupil and the student of pedagogical institution are involved.

Key words: partner training, independent activity, research work, creative thinking.

Існує думка, що рівень знань 3 фізики значно знижується 3 того моменту, коли термін навчання в школі змінювався 3 10- 